\title{
Papers
}

\section{Toward an Engagement Model of Institutional Advancement at Public Colleges and Universities}

Received (in revised form): June 14, 2007

\section{David J. Weerts}

is an assistant professor of higher education in the Department of Educational Leadership at Florida Atlantic University and a faculty affiliate at the Wisconsin Center for the Advancement of Postsecondary Education (WISCAPE), University of Wisconsin-Madison. He has nine years of experience in advancement, and has held major gifts officer positions at the University of Wisconsin Foundation and University of Minnesota Foundation.

\begin{abstract}
Enrollment pressures, unstable state appropriations, and increased public scrutiny about higher education's commitment to serving societal needs have created significant challenges for university advancement professionals at public colleges and universities in the United States. In this paper, I describe how current responses to these challenges may ultimately encourage privatization of public higher education. In order to keep the "public" in public higher education, I propose an engagement model of institutional advancement that focuses on creating a public agenda for higher education.
\end{abstract}

\footnotetext{
Author's Contact Address:

David J. Weerts

Department of Educational Leadership

Florida Atlantic University

777 Glades Road

Boca Raton, FL 33431, USA

Phone: +1561 2973370

Fax: +1 5612973618

Email: dweerts@fau.edu
}

Anchored in knowledge flow theory, my analysis suggests that an engagement approach to advancement would generate public and private support for public higher education, and more broadly benefit students, communities, and society at large. Practical strategies for institutional advancement leaders are discussed. International Journal of Educational Advancement (2007) 7, 79-103. doi:10.1057/palgrave.ijea.2150055

\section{Keywords:}

institutional advancement, public engagement, knowledge flow theory

\section{Introduction}

"Fasten your seat belts. We're in for a bumpy ride!" This famous line from a 1950s Hollywood script was recently used by noted historian John Thelin to foreshadow the challenges that American higher education would face during the past quarter century. The 
quote references the enormous demographic, fiscal, political, and philosophical changes that have taken place in public higher education since the "golden age" of the 1960s. Higher education's bumpy ride has been attributed to both internal and external forces shaping colleges and universities during the last 25 years.

Most significantly, higher education in the US is experiencing dramatic demographic changes. Minority student enrollment in US colleges and universities has increased by 51 percent from 1993 to 2003 (Porter, 2006) and is expected to rise rapidly through 2015 (Woo, 2006). Overall college enrollment is projected to rise steadily in the next decade in the wake of the baby boomlet (Jacobson, 2004). Today, higher education leaders are faced with the challenge of ensuring access for an expanding and increasingly diverse generation of students (Ward, 2000).

Higher education's role in the global US economy is also changing. Rapid advances in information technologies during the last two decades have fueled a new kind of knowledge economy where institutions are moving away from distribution and analysis of knowledge-to-knowledge creation and innovation. Globalization of commerce, communications, labor, and culture has heightened the role of colleges and universities as national and international economic engines. In this high-stakes environment, the cost, price, and value of a college degree continues to increase (Duderstadt, 2003).

While these challenges mount, higher education leaders argue that they have less public money to address them. Adjusting for inflation, state appropriations for higher education have dropped 40 percent since 1978 , and current state investment effort per personal income has declined \$32.1 billion below that of 1980 (Mortenson, 2004). This phenomenon has led Mark Yudof, President of the University of Texas System, to declare that the compact that once governed states and public universities "has withered, leaving public research universities in a purgatory of insufficient resources and declining competitiveness" (Yudof, 2002, p. B24).

Scholars agree that the consequences of declining state appropriations for higher education are dire. If present trends persist, public higher education will continue to face rising tuition, tightening enrollments, cuts in financial aid, increased attrition rates, and decline in faculty salaries (Ehrenberg, 2006). Consequently, market forces will reinforce admissions strategies where public institutions compete for top students who can raise institutional rankings or pay full price for their education. The result is a diminishing role for public higher education in society (Newman et al., 2004).

Alongside of these external forces are internal struggles to reclaim the soul of American higher education. Once viewed as the answer to poverty, racism, and other social ills, higher education today is often viewed as wasteful and overpriced and failing to deliver on its promises. As a result, higher education is increasingly viewed as a private consumer good than as a public good. Consequently, traditional rationales for public funding of higher education have broken down (St. John and Parsons, 2004). Michigan State University President, Lou Anna Simon summarized this dilemma, "Society has come to see its universities as providers 
of education-as-commodity, that is, a personal investment decision made by a student to achieve future personal gain. Research on the public's perception of higher education affirms that many have lost sight of how universities contribute to the public good" (National Forum on Higher Education for the Public Good, 2006).

Thelin (2004) suggests that universities must bear some responsibility for the mixed perceptions about higher education. $\mathrm{He}$ argues that colleges and universities have had increasing difficulty in explaining themselves to external audiences because they have drifted in character and mission. As a result, today's colleges and universities face uncertainty in their societal roles. The result of all these factors is that American higher education in the last quarter century has become a "troubled giant" (Thelin, 2004, p. 147).

\section{Institutional Advancement and the "Troubled Giant"}

In this difficult environment, institutional advancement officers are faced with tremendous challenges. In this next section, I outline four primary strategies that have been employed by advancement and external relations officers to garner support for their public colleges and universities. In so doing, I address the limitations of these strategies and how they ultimately contribute to the erosion of the "public" in public colleges and universities.

For the purposes of this paper, institutional advancement refers to campus external relations offices charged with building relationships with a full range of external stakeholders: alumni, donors, community partners, corporate partners, state legislators, governors, and other government officials at the state, federal, and local level.

\section{Strategy \#1: “Tell our story better} to the legislature"

A view among some institutional advancement officers is that higher education has simply failed to apply the basic principles of marketing. From this perspective, colleges and universities face their present plight due to their inability to effectively "tell their story" to public officials. The sentiment is, "Legislators just don't understand the impact we make on this state and region. We need to do a better job of getting our message out. If we only told our story in a more compelling way, we could get more support."

One popular strategy used by institutional leaders to market higher education is to commission economicimpact studies to illustrate the benefits of higher education in dollars and cents. These studies typically calculate institutional, faculty, student, and visitor spending, along with other economic contributions to the state and region. For example, an economicimpact study conducted for the University of Wisconsin System found that the System contributed 2.7 percent of the gross state product (Potter, 2003).

Despite these efforts, government relations experts agree that repackaged marketing strategies have had little impact on legislative and gubernatorial inclinations to support higher education (Big Ten Government Relations Conference, 2004). Expensive economic reports sponsored by university relations office have been 
scrutinized for their inaccuracy and are often "taken with a grain of salt" by state officials. It remains unclear how such studies help institutions in the face of budget deficits and competing interest groups vying for a diminishing share of state funds (Potter, 2003). Still, others suggest that improved marketing efforts will have little impact on state support for higher education because the current financial crisis facing institutions may be more structural than political (Lyall and Sell, 2006). Overall, the current strategy of "telling our story better" has its limits in advancing colleges and universities the current fiscal and political environment.

\section{Strategy \#2: “Negotiate more favorable state-university relationships"}

Another strategy for navigating the tenuous relationship between the public and colleges and universities is to negotiate new relationships between higher education and state governments. State enterprises, charters, contracts, and public-private hybrids are being developed to provide increased institutional freedom in exchange for reduced state support. For example, the Colorado School of Mines was given a lump sum budget and greater control over tuition and programs in return for an agreement to meet specific performance goals. Higher education leaders and state officials in Oregon, North Dakota, Arizona, Florida, Iowa, Virginia, and Washington are having similar discussions regarding new stateuniversity relationships (Couturier, 2003).

While these new arrangements yield benefits to both states and institutions, they must be considered cautiously. Without centralized oversight, campuses are likely to go in directions that may duplicate educational efforts elsewhere in their state. Institutional control over tuition may lead to tuition hikes, reduced access for lowincome students, and institutional incentives to recruit only affluent students. As regulations are loosened and market forces take over, there is no guarantee that institutions will fulfill their public missions (Couturier, 2003).

Fundamentally, these new relationships create profound changes in the historic relationship between public higher education and society. Under these new arrangements, state higher education policy is reduced to monitoring static performance indicators such as graduation rates and progress on diversity goals. Any collective efforts to identify larger regional, state, and national needs are neglected. These emerging stateuniversity relationships might be compared to an amicable divorce, where both parties compromise and separate without the burden of creating a meaningful dialogue about how higher education and states can work together to address the concrete needs of their citizens.

\section{Strategy \#3: “Raise more money from alumni and friends"}

As public institutions rely more heavily on private support to keep their programs competitive, high-powered fundraising machinery has emerged across the country. Sophisticated prospect research, donor communications, annual and major gift strategies, stewardship programs, and innovative 
deferred giving vehicles have contributed to the professionalization of the field over the past 20 years. These efforts have paid off handsomely as evidenced by the success of billion dollar fundraising campaigns recently completed by public institutions across the country (Pulley, 2003).

Fund raising will remain an important strategy for public institutions as they face the realities of today's political and fiscal environment. At the same time, institutions may vary in their capacity to reap the benefits of fund raising. For example, studies on alumni giving show that household income is significantly associated with support for one's alma mater (see Baade and Sundberg, 1996; Clotfelter, 2003; Monks, 2003). These findings suggest that institutions that produce high wage earners are more likely to receive higher levels of alumni gifts over time.

Consequently, prestigious national universities offering expansive professional programs have an advantage over smaller, regional liberal arts-oriented institutions that are less likely to produce wealthy graduates. This poses a considerable disadvantage for community colleges leaders who are increasingly seeking to get their alumni involved in major gift programs.

Another important issue is that donor gifts are typically earmarked to support specific programs and are not available for discretionary support. Thus, private gifts have the potential to alter the direction of mission of the university itself. For example, at many public research universities, most of the private gifts have been directed to the professional schools, a trend that could threaten the basic liberal arts mission of the university (Ward, 2000). Therefore, university foundations may be more likely to invest staff resources in departments that have the greatest fundraising potential. In this environment, important programs serving public interests (e.g., social work, nursing) may have less opportunity to enhance their standing through private gifts as compared to commercial ventures like business and engineering.

\section{Strategy \#4: “Enhance entrepreneurial ventures and technology transfer"}

Since the 1970s, institutions have been engaged in significant efforts to secure external money through commercialization of academic products. Global market forces, declining state support for higher education, and the passing of the BayhDole Act of 1980 have provided significant incentives for institutions to engage in market activity to improve their financial position. Increased efforts in university technology transfer and entrepreneurialism have contributed to a culture of academic capitalism where faculty are becoming intensely focused on profit maximization (Slaughter and Leslie, 1997).

University technology transfer provides tremendous benefits to society by speeding up the delivery of new cures and technologies to be used by the public. At the same time, it is clear that technology transfer is not a viable strategy for institutions to address their financial future. Many university leaders have unrealistic expectations about the results of their technology transfer, and more than half of all 
institutions lose money on these efforts (Powers, 2006). As one scholar put it, "The current technology transfer process has done a better job of raising universities' financial hopes than it has of realizing them" (p. B18).

Institutions that are desperate to hit a home run in technology transfer are left vulnerable to ethical dilemmas. Without appropriate oversight, conflicts of interests may go unreported and students may be exploited as cheap labor to the detriment of their education. In the end, such practices could further erode the public trust in public research universities leading to increased government regulations and a faster decline in taxpayer support (Powers, 2006). In sum, technology transfer plays an important role in public research university missions but has limits in producing steady revenues.

\section{Where Do We Go From Here?}

All of the above strategies have limitations that ultimately do not help public institutions deal with the momentum of de facto privatization. "Telling our story better" to state officials has been ineffective, and new state-institutional structures have reinforced the divide between state governments and public higher education. While raising money from alumni and friends is an important strategy, success may be limited to particular programs and institutions for which there is market potential. Finally, entrepreneurial ventures such as technology transfer provide an important benefit to society, but are unlikely to support a consistent flow of revenue. In all these scenarios, the character of public universities is being reshaped to reflect private interests. As a result, the notion of higher education for the public good continues to lose steam.

For the remainder of this paper, I advance a new course for institutional advancement aimed at strengthening higher education's fiscal position while forging a deeper, more meaningful, relationship with the public. I argue that improved financial stability for public higher education is predicated on a more authentic relationship with external stakeholders that emphasize reciprocal sharing of knowledge and resources. Specifically, the concept of university engagement is essential to reestablishing public confidence and support for higher education and leveraging public and private support for its programs. An examination of the emerging national movement toward universitycommunity engagement provides the basis for these ideas.

\section{Reclaiming the Civic Mission of Public Higher Education} During the last decade, a national movement has emerged to renew the civic mission of US colleges and universities. As criticisms about higher education's relationship with society grew, the 1990s introduced a new terminology to describe how institutions might reform their service activities to better meet public needs. While traditional conceptualizations of public service and outreach emphasized a one-way approach to delivering knowledge and service to the public, innovative leaders of public service and outreach began using the term "engagement" to describe a two-way 
approach to interacting with community partners to address societal needs (Boyer, 1996; Kellogg Commission on the Future of State and Land-Grant Universities, 1999). The new philosophy emphasizes a shift away from an expert model of delivering university knowledge to the public, toward a more collaborative model where community partners play a significant role in creating and sharing knowledge to the mutual benefit of institutions and society.

The American Association of State Colleges and Universities (AASCU) Task Force on Public Engagement characterizes an engaged institution in this way: "The publicly engaged institution is fully committed to direct, two-way interaction with communities and other external constituencies through the development, exchange, and application of knowledge, information, and expertise for mutual benefit" (American Association of State Colleges and Universities, 2002, p. 7).

Significant national levers have emerged to facilitate institutional shifts toward public engagement. Professional organizations including the National Association of State Universities and Land Grant Colleges, American Association of State Colleges and Universities, and American Association of Community Colleges, have developed major initiatives to promote a civic-oriented agenda among campus presidents, faculty, staff, and students. Seminal works such as Scholarship Reconsidered (Boyer, 1990), Scholarship Assessed (Glassick et al., 1997), and Making the Case for Professional Service (Lynton, 1995) have also paved the way for supporting faculty work focused on serving broad public interests (Knox, 2001).

In 2006, the Carnegie Foundation for the Advancement of Teaching developed a new classification to recognize a category of "community engaged institution" that define themselves by their commitment to the ideals of public engagement (Carnegie Foundation for the Advancement of Teaching, 2006). In addition, the North Central Association of Colleges and Universities has begun to include engagement as a key measure of institutional quality (Higher Education Learning Commission, 2006). The work of these national organizations has served to legitimize the public engagement movement across the country. Thirty-eight national organizations have since developed a federation for action around these activities (Sandmann and Weerts, 2006).

\section{A Theoretical Map of Engagement}

What is engagement and why is it important to securing the future of public colleges and universities? To address this question, one must first identify what engagement is and what it is not. Many campuses claim that that they are "doing engagement" but in reality, "there is more smoke than fire" (American Association of State Colleges and Universities, 2002, p. 15). For this reason, a theoretical framework is needed to unpack the concept of engagement and how it informs an improved course for institutional advancement.

The concept of engagement has evolved from competing notions about origins of knowledge: how knowledge 
is produced, where knowledge is "found," and how knowledge flows and is distributed. The knowledge flow theory examines the transfer of knowledge within and across settings with the assumption that knowledge will result in learning, exchange of information or perspectives, acquisition of new perspectives and attitudes, or increased ability to make informed choices among alternatives (Hutchinson and Huberman, 1993).

The field of knowledge utilization is vast and spans a number of disciplines including rehabilitation, education, sociology, psychology, and marketing. Recognizing the depth and breadth of research in the field, my analysis draws extensively on three exhaustive literature reviews that outline the history, evolution, and contemporary models of knowledge utilization theory (see Hutchinson and Huberman, 1993; Hood, 2002, and National Center for the Dissemination of Disability Research, 1996.)

A traditional view of an institution's role in knowledge creation and dissemination is linear and unidirectional. In this worldview, knowledge itself is viewed from an objectivist epistemology emphasizing logical thinking rather than understandings. Knowledge is viewed as value neutral, detached, and "existing on its own." From this perspective, knowledge is viewed as a commodity that can be transferred from a knowledge producer to a user. This philosophy views the brain as a blank slate or empty vessel in which knowledge must be poured (National Center for the Dissemination of Disability Research, 1996). From this perspective, the university's role is to produce knowledge to be shared with users (stakeholders) who are its consumers.

Dissemination strategies in the unidirectional approach can be characterized as spread and choice (Hutchinson and Huberman, 1993). Spread refers to a one-way broadcasting of knowledge from institutions to stakeholders without regard to utilization and acceptance of this knowledge outside the organization. Choice is also a one-way dissemination approach, but involves producing alternatives for users to compare strategies for implementation. In both strategies, boundary spanners play a role in delivering knowledge from producer to user.

In the context of higher education, the unidirectional approach is best understood through the agricultural extension movement associated with land-grant colleges. Agricultural extension was developed as a one-way process of university researchers sharing new agricultural technologies to be used by farmers. In this model, extension field agents translate research findings into terms understandable by farmers and convince them to use the new knowledge. While these efforts initially proved successful, dissemination efforts were less successful when the subject matter moved away from the topic of agricultural technology (Mundy, 1992).

Despite its limitations, this traditional model remains the dominate paradigm for the universitystakeholder relationships: the university produces knowledge and, if applicable, stakeholders consume it. Today, the rhetoric about higher education's contribution to society is typically articulated within this unidirectional language. For example, in his recent 
book, What's happening to public higher education?, economist Ronald Ehrenberg discusses the value of land grant universities as "major transmitters of knowledge to American farmers, consumers, and workers, and industry" (Ehrenberg, 2006, p. xix.)

During the mid-1970s, however, some theorists began to adopt a more inclusive, two-way approach to knowledge flow. This model emerged because the linear model was increasingly shown to be ineffective since it failed to take into account the motivations and contexts of intended recipients (Berman and McLaughlin, 1978). For example, researchers learned that top-down programs were ineffective in institutionalizing ideas into the curricula of local schools. Their analysis led them to reject the assumption that one can simply pass on information to a set of users and expect that learning will result (Hutchinson and Huberman, 1993). Instead, researchers stated that new understandings must be "grafted into prior understandings, and individuals must have ample opportunity to experience the new information and develop their understanding of its meaning" (p. 10).

The transition to the two-way approach was accompanied by an epistemological shift, which moved from a rational or objectivist worldview to a constructivist worldview (Hutchinson and Huberman, 1993). Constructivism suggests that the knowledge process is local, complex, and dynamic. In this paradigm, learning takes place within a context where knowledge is applied (Hood, 2002). This constructivist model replaces the empty vessel metaphor with a community of learners metaphor (Hutchinson and Huberman, 1993).

In a constructivist paradigm, dissemination strategies vary considerably from the unidirectional model. Instead of broadcasting knowledge and offering alternatives to users, boundary spanners (e.g., university outreach officers) act as conveners, problem solvers, and change agents that negotiate the wants and needs of stakeholders involved in the knowledge creation and dissemination process. The one-way dissemination strategies of spread and choice are replaced by two-way interactive strategies of exchange and implementation. Through exchange and implementation, researchers and stakeholders develop shared solutions to problems of mutual interest (Hutchinson and Huberman, 1993).

The two-way constructivist approach to knowledge flow embodies the core concepts of engagement. Reciprocity is the key animating principle and represents an authentic give and take among institutional and external partners. In this model, external stakeholders are not merely consumers and supporters of knowledge producers, but partners in the creation, dissemination, and implementation of knowledge. Simply put, the engagement model expands traditional university teaching, learning, and scholarly inquiry to include external stakeholders in a community of learners. The ultimate goal of this model is not knowledge distribution, but systemic change in communities and society at large. Table 1 provides an illustration of this theoretical framework as it informs an examination of traditional and 
Table 1: Models of knowledge flow in higher education

\begin{tabular}{|c|c|c|}
\hline & $\begin{array}{l}\text { Traditional unidirectional model } \\
\text { (one-way approach) }\end{array}$ & $\begin{array}{l}\text { Engagement model } \\
\text { (two-way approach) }\end{array}$ \\
\hline Epistemology & $\begin{array}{l}\text { Positivist: Knowledge is value } \\
\text { neutral, detached and "exists } \\
\text { on its own." Logical, rational } \\
\text { perspective. }\end{array}$ & $\begin{array}{l}\text { Constructivist: Knowledge is } \\
\text { developmental, internally constructed, } \\
\text { and socially and culturally mediated } \\
\text { by partners (researchers and } \\
\text { stakeholders). }\end{array}$ \\
\hline $\begin{array}{l}\text { Role of higher education } \\
\text { institution and } \\
\text { stakeholders }\end{array}$ & $\begin{array}{l}\text { University produces knowledge } \\
\text { through traditional research } \\
\text { methodology (labs, controlled } \\
\text { experiments, etc.). Roles and } \\
\text { functions of labor, evaluation, } \\
\text { dissemination, planning separated } \\
\text { from researcher and users. Users } \\
\text { have little input into the research } \\
\text { design. }\end{array}$ & $\begin{array}{l}\text { Learning takes place within context } \\
\text { in which knowledge is applied } \\
\text { (stakeholders). Knowledge process } \\
\text { is local, complex, and dynamic and } \\
\text { lies outside the boundaries of the } \\
\text { institution. Knowledge is embedded } \\
\text { in a group of learners (stakeholders } \\
\text { and institution). }\end{array}$ \\
\hline Boundary spanning roles & $\begin{array}{l}\text { Field agents deliver and interpret } \\
\text { knowledge to be adopted by users. }\end{array}$ & $\begin{array}{l}\text { Field agents interact with stakeholders } \\
\text { at all stages: planning, design, } \\
\text { analysis, implementation }\end{array}$ \\
\hline $\begin{array}{l}\text { Dissemination philosophy } \\
\text { and strategies (Hutchinson } \\
\text { and Huberman, 1993) }\end{array}$ & $\begin{array}{l}\text { Dissemination paradigm } \\
\text { Spread: One-way broadcast of new } \\
\text { knowledge from university to users } \\
\text { Choice: University produces } \\
\text { alternatives for users to choose }\end{array}$ & $\begin{array}{l}\text { Systemic change paradigm } \\
\text { Exchange: Institutions and } \\
\text { stakeholders exchange perspectives, } \\
\text { materials, resources } \\
\text { Implementation: Interactive } \\
\text { process of institutionalizing ideas } \\
\text { (stakeholders and institutions) }\end{array}$ \\
\hline Metaphors & $\begin{array}{l}\text { Users as "empty vessel" to be } \\
\text { filled. Knowledge is a commodity } \\
\text { to be transferred to users. }\end{array}$ & $\begin{array}{l}\text { Stakeholders and university true } \\
\text { partners in a "community of } \\
\text { learners." Universities become } \\
\text { a learning organization. }\end{array}$ \\
\hline
\end{tabular}

engagement models of knowledge flow at colleges and universities.

\section{The Case for Engagement}

Institutions, institutional advancement offices, and the general public have much to gain by transitioning from a linear, unidirectional model of knowledge transfer to a two-way constructivist paradigm of systemic change. Specifically, the engagement model yields six specific benefits to institutions and their stakeholders.
First, engagement enhances teaching and learning. University-community engagement is often expressed through undergraduate curriculum focused on service learning. Service learning is defined as a "teaching and learning strategy that integrates meaningful community service with instruction and reflection to enrich the learning experience, teach civic responsibility, and strengthen communities" (National Service-Learning Clearinghouse, 2006). Among its many benefits, service 
learning strengthens students' analytical and critical thinking skills, communication skills, and promotes the values of diversity and civic responsibility (Learn and Serve America, 2006).

Second, engagement enhances research and scholarship. Involving stakeholders in developing research directions helps researchers develop important lines of inquiry that may not have been considered in a traditional setting. In addition, stakeholder input may help scholars think differently about traditional theoretical frameworks and interpretation of research findings. As such, "engaged" scholarship provides researchers with expanded opportunities to test theory with practice, resulting in improved quality of the work and in greater likelihood of implementation of solutions. This work is typically referred to as public scholarship (see Peters et al., 2005). When designed properly, scholarship embedded in community issues is equally as rigorous and high quality as traditional research (Boyer, 1996).

Third, porous structures supporting engagement allow institutions to more effectively serve the public good. A criticism of traditional higher education structures is that they are rigid and are overly protective of academic culture. The phrase "Society has problems, institutions have disciplines" articulates the organizational issues facing campuses as they strive to be more responsive to societal needs (Kellogg Commission on the Future of State and Land-Grant Universities, 1999). While traditional structures reinforce isolation and a separatist culture among academic researchers and stakeholders, engaged institutions flatten the hierarchical relationship of "researcher over user." The prevailing ivory tower culture of institutional separateness is replaced by an inclusive culture of equitable partnerships.

Fourth, engagement supports the emerging interdisciplinary culture unfolding on campuses across the country. In his 2000 article, "Catching the Waves of Change in Higher Education," American Council on Education President, David Ward described a new academic division of labor where traditional disciplinary boundaries are breaking down and collaborative research among separate fields of knowledge is emerging (Ward, 2000). Advocates of interdisciplinary collaboration argue that creative research and teaching increasingly occur between the disciplines (Pfirman et al., 2005) and this approach is increasingly rewarded by national funding organizations including the National Science Foundation (Brainard, 2002). The engagement model of knowledge flow supports interdisciplinary research because it places institutions as a collaborative partner in a larger system of knowledge organizations working to improve society.

Fifth, there is evidence that engagement strengthens public financial support for colleges and universities. Some of my past research suggests that institutional commitment to outreach and engagement was associated with increased levels of state appropriations for public research universities during the 1990s. In other words, institutions that received higher levels of appropriations than predicted were more authentically engaged in service to their states compared to those that 
received less money than predicted (see Weerts and Ronca, 2006). Obligatory action theory was one construct advanced to explain this relationship. In short, this theory suggests that state funding decisions are based on contractual implicit agreements to act appropriately in return for being treated appropriately (March, 1981). In this case, state legislators acted appropriately (supported institutions) in return for being treated appropriately (state and community needs were met). My analysis suggests that engagement not only provides benefits to teaching, learning, and society at large, but also has the capacity to garner increased public support for colleges and universities (see Weerts, 2002; Weerts and Ronca, 2006).

Sixth, engagement has the capacity to leverage major private gifts for higher education. An emerging body of literature suggests that the concept of engagement fits squarely with a new generation of donors seeking acceptance of their ideas and opinions, not just their money. These donors are motivated by giving opportunities that will make a tangible impact on society. As such, fundraising professionals must view these donors as long-term social investors instead of responders to traditional fundraising appeals (Grace and Wendroff, 2001).

\section{Venture Philanthropy Repackaged?}

The last point above is especially important and merits more discussion. In short, the new philanthropic movement associated with satisfying a new generation of donors is called venture philanthropy or high engagement philanthropy. The signature elements of venture philanthropy include close relationships between investor and investee, a longterm commitment between donor and institution, and an emphasis on outcomes. Donors in this model provide not only money but also expertise, typically in the area of organizational capacity building (Boverini, 2006).

At first glance, venture philanthropy seems to hold promise for drawing donors toward a more authentic twoway relationship with institutions. The motives of institutions, however, must be examined more closely. As one development officer explained, "A good development officer has the ability to make a venture philanthropist believe that the institution's goals are her own" (Boverini, 2006, p. 99). This quote calls into question whether venture philanthropy really represents a new kind of relationship with donors or is a repackaged strategy to raise major gifts for a preset agenda. Developing inauthentic partnerships might have the effect of alienating donors who expect to enter into mutually beneficial relationships with institutions.

Advocates of venture philanthropy in higher education must also address whether campuses have the authentic desire to involve donors more broadly in shaping the agenda of their campuses. For example, donors may have valuable experience in strategic planning, but are typically excluded from these exercises because their participation would be outside of institutional norms (Boverini, 2006). Similarly, development officers in this new movement take the role of "idea processors" by determining venture philanthropists perceived needs for the 
institution (p. 98). This approach fails to establish an interactive learning process where institutional leaders and donors develop a shared vision to address key societal issues. In other words, the "new" role of the development officer in venture philanthropy seems to rely on old strategies of matching donor interests and institutional interests. In this environment, the distinct cultures of institution and donor remain separate.

Based on early evidence, venture philanthropy or high engagement philanthropy fails to pass the test of true engagement as articulated in the theoretical framework of this study. Instead, authentic engagement must stem from shared culture, shared vision, and an authentic exchange of ideas between partners.

Transformational gifts received by engaged institutions must be the result of innovative ideas generated by a community of learners-institutions and donors-dedicated to common ends. The following section suggests a new course for institutional advancement embedded in these values.

\section{Toward an Engagement Model of Institutional Advancement}

This paper has outlined evidence that engagement greatly benefits student learning, faculty research, and society at large. It was also shown that engagement has the potential to garner greater support for higher education among public officials. Finally, this paper suggests that engagement fits squarely into a new generation of donors seeking to be more actively involved with their giving. Engagement shows great promise as a lever to inspire donors to make transformational gifts to higher education.

A shift toward engagement requires significant transformation at all levels of an institution. A growing body of literature addresses how campus leadership, structure, faculty rewards, and institutional culture might be managed to facilitate this shift (see Votruba, 1996; Ward, 1996; Holland, 1997; Zlotkowski, 1998; Walshok, 1999; Bringle and Hatcher, 2000; Maurrasse, 2001). The remainder of this paper envisions a new model for institutional advancement and considers the question, "What might institutional advancement look like at an engaged college or university?"

The knowledge flow theoretical framework presented earlier in this paper is instructive to understanding how institutional advancement might operate in this new environment. Under an engagement model of advancement, external relations officers-development, government relations, alumni relations, corporate relations, community relations-have a critical role in facilitating institutional transition toward a deeper, more authentic relationship with external stakeholders to the mutual benefit of their campuses and society at large. To set the stage for this new model, one must first consider the current practice of advancement in higher education.

\section{Traditional model of institutional advancement}

Today's traditional advancement model is built on the unidirectional model of 
knowledge flow articulated in this paper. It is guided by key assumptions about the distinctive roles of higher education and stakeholders in creating, disseminating, and applying knowledge. The epistemology informing this worldview is that knowledge is value-neutral and exists "on its own" to be found by a university researcher or faculty member. As such, the mission of the university is carried out through traditional modes of classroom instruction, research, and outreach aimed to deliver new knowledge from the university to the public.

The role of advancement in this traditional paradigm is to spread the word about the new pedagogies, knowledge, and innovations being created within the walls of the university. Advancement officers broadcast this information to promote this work to external stakeholders. For example, campus brochures, annual reports, legislative and donor visits, community forums, and alumni events typically aim to showcase faculty and student work underway inside the institution. In this setting, development officers are charged with the task of matching the institution's work with interests of external partners. Similarly, government relations staff lobbies the legislature about the campus programs that merit additional public support. This method of advancement can be described as the dissemination paradigm of "choice" as discussed in Hutchinson and Huberman (1993). In this model, university advancement officers prioritize their programs and offer stakeholders a range of alternatives to support.

In the traditional advancement model, advancement culture, academic culture, and external stakeholders are separate and sometimes in conflict. Each group is guided by differing sets of values expressed through their own unique traditions, practices, and beliefs. Despite these differences, each have found their own role in higher education: academics create learning programs and new knowledge, advancement officers promote these programs as funding opportunities, and external stakeholders either support or reject these funding opportunities.

The three groups interact through structured participation strategies founded on a development cycle (see Gray, 2005). When courting alumni, institutions typically sort major gift prospects by the type of degree earned, college affiliation, and department affiliation of degree. Based on this information, alumni prospects are routed to support programs within the college they earned their degree. These prospects are then cultivated by the appropriate school or college development officer through home and office visits, campus visits, and membership on college, department, or institutional advisory boards. In the next step, campus leaders and development staff solicit support for campus priorities consistent with the donor's background. Donor's personal interests are considered in the solicitation process; however, the range of giving opportunities presented to the donor is typically limited. For example, under this model, development officers assume that an alumnus who earned a BS in geography will naturally want to support the Department of Geography many years later. Finally, if the prospect makes a gift, 
advancement officers steward these gifts through fund reporting, letters of thanks, visits, and other

strategies.

Government relations and corporate and foundation relations officers operate under a similar cycle with their constituencies. Lobbyists arrange campus visits, capitol visits, and relationship-building opportunities in their efforts to "prioritize, show, tell, and solicit" public support for campus programs. Corporate relations executives engage in similar strategies to match institutional interests with corporate interests.

Faculty, academic staff, and students play a limited role in the traditional model of advancement. Faculty and academic staff members are often featured by advancement staff in "show and tell" forums where they feature elements of their work of interest to particular stakeholders (alumni, donors, legislators, etc.). In these settings, faculty and staff typically present their findings with limited dialogue with the stakeholder groups. Instead, faculty may independently form their own corporate, foundation, or community relationships that may assist in developing their teaching, research, or service agenda.

Similarly, students have little role in advancement and are typically passive beneficiaries of support. They often serve as marketing tools for advancement staff at alumni dinners and campus tours to put an enthusiastic face on funding proposals. In these cases, the best students are often "paraded around" to top prospects but fail to make any meaningful connections with stakeholders who are often very interested in their experiences and aspirations.

\section{Engagement model of advancement}

The engagement model of institutional advancement is built on profoundly different assumptions compared to the traditional model. The engagement model is anchored in the two-way knowledge flow model as illustrated in Table 1. This model is characterized by a constructivist view of knowledge, suggesting that knowledge is developmental, internally constructed, and socially and culturally mediated by internal and external partners. The underlying premise of engagement is that knowledge exists inside and outside of traditional boundaries. As a result, this worldview accommodates for external stakeholders and advancement officers themselves to be part of the larger teaching and learning community in higher education.

Instead of "spreading the word" about the new knowledge being created in the walls of the university, advancement officers within the engagement model seek to facilitate meaningful exchanges between institutions and external partners to create systemic changes in communities and society at large. In this environment, advancement staffdevelopment, government relations, corporate/foundation relations, alumni relations, community relations-work together to facilitate an interactive process of teaching, learning, and problem solving in which institutions and external partners exchange perspectives, knowledge, materials, and resources. 


\section{Building a publicly engaged office of institutional advancement}

So what might the engagement model look like in its day-to-day operation? In this section, I outline strategies for creating a university advancement division anchored in the engagement model of knowledge flow. The signature element of this model is the creation of a shared public agenda with institutional and external stakeholders. This public agenda is developed through focus groups and one-on-one dialogues with stakeholders to map future directions for the institution. These stakeholders include legislators, community groups, corporate partners, alumni, philanthropists, and other key partners who have a stake in improving their region, state, and nation at large. The main idea is that stakeholders are given an opportunity to share perspectives about key issues necessary to improving the quality of life in their community, state, and nation as a whole.

Identifying and cultivating stakeholders to partake in these dialogues would look much different than traditional models of identification and cultivation. Consider the example of recruiting alumni to support a particular school or college. Instead of recruiting and sorting alumni by their degree affiliation to eventually support a specific program, development officers would meet prospects with an open agenda. The primary goal of the development officer would be to carefully listen to the prospect, develop an understanding of his or her values, and create a profile about key issues most important to that prospect. For example, a prospect who has a child with autism may be passionate about finding support and cures for children with disabilities. Another prospect may be active in conservation issues and care deeply about ecological restoration. Still, another prospect may have spent a life dedicated to the arts. These interest profiles provide the basis for their future involvement with the university.

Consider the role of government relations in this context. In formulating a shared public agenda, government relations officers would play a role in carefully monitoring the key policy issues of concern to state, local, and federal officials. These university relations professionals would take a proactive stance in developing legislative and gubernatorial relationships by asking public officials, "How could our institution improve the lives of citizens in our region, state, and nation?" This open-ended discussion would move institutions away from a central lobbyist role (unidirectional approach) toward a more authentic dialogue about the institution's role in the community and state (engagement approach). The key themes emerging from this analysis would provide the basis for developing a long-term reciprocal relationship with public officials and the public at large. Similar strategies could be employed by corporate and foundation relations officers and community relations staff to understand the key themes most important to their constituencies.

The findings of this broad based data collection would form the basis for a shared agenda for a "public purpose" university as discussed by Lyall and Sell (2006). From this strategic exercise, key themes would 
emerge focusing on significant areas of public interest. Informal structures, such as an Interdisciplinary Council, would be put in place to house these public agenda themes, generate stakeholder input and learning pertaining to this work, and cultivate stakeholder financial support to carry out the public agenda. For example, one could anticipate forming a Council for Environmental Stewardship focusing on institutional roles in teaching, learning, and research related to environmental issues. Similarly, a Council for Cultural Enrichment might be formed to advance work in the arts. At a major research university, a Council on Disease Treatment and Prevention might capture progress underway in professional schools focused on human health.

Within the council structure, individuals would work in crossstakeholder teams to address key issues pertaining to that council. Consider, for example, a discovery team housed under the Council on Disease Treatment and Prevention. The alumni donor prospect who is interested in issues of autism may join a "Childhood disorders discovery team" comprised of diverse stakeholders who share her interest in addressing childhood diseases. Stakeholders in this team may include faculty, graduate students, and undergraduate students studying a range of biological or social factors associated with curing or caring for children with developmental disorders. The team may also be comprised of state officials who are passionate about improving policies supporting children with disabilities. Foundation representatives or advocates from nonprofit groups may also join the team to expand networks of support for this work. Finally, corporate partners may join the group to consider new technologies that may improve life for children with disabilities.

Discovery teams would meet biannually for the purpose of updating team members about new curriculum or research in the field, emerging public policies relevant to the issue, technology transfer, or other factors influencing future directions for this public work. A key role of the team would be to help development and government relations officers identify, cultivate, and solicit private and public support to advance the team's goals. It is assumed that the appropriate major donors and political advocates would serve on these teams and play key philanthropic and advocacy roles.

In this new model, campus leaders (deans, directors, chairs, advancement officers) cultivate prospects one-on-one in the context of team and council goals. Campus executives play an especially important role in articulating the overall needs of the institution as it relates to the shared public agenda. They also serve by selecting and training council and discovery team leadership. With campus colleagues, they seek out appropriate stakeholder membership on teams and councils and solicit their participation.

Overall, the council and discovery team concept is similar to institutional, school, and college advisory boards on campuses today. The program as described above has, however, several advantages over traditional boards. First, the council and discovery team model stems from a public agenda representing a diverse body of 
stakeholders. The institution's work is guided by compelling societal issues and thus improves its capacity to serve the public good. Since stakeholders in the engagement model are more intimately involved in shaping the future of the institution and serving public needs, they are more likely to become invested in its success and support. In short, it would be made clear that institutions and stakeholders share this public agenda as well as the responsibility for executing and supporting it.

Second, the discovery team concept embraces a community of learners

Table 2: Traditional and engagement models of institutional advancement

\begin{tabular}{|c|c|c|}
\hline & Traditional model of advancement & Engagement model of advancement \\
\hline Epistemology & $\begin{array}{l}\text { Positivist: Knowledge is value neutral } \\
\text { and detached. Knowledge is } \\
\text { "out there" to discover and found } \\
\text { through university methodology. }\end{array}$ & $\begin{array}{l}\text { Constructivist: Knowledge is } \\
\text { developmental, internally constructed, } \\
\text { and socially and culturally mediated } \\
\text { by internal and external partners. }\end{array}$ \\
\hline $\begin{array}{l}\text { Role of institution and } \\
\text { external partners }\end{array}$ & $\begin{array}{l}\text { Campus mission carried out } \\
\text { through traditional means } \\
\text { (classroom instruction, research, } \\
\text { one-way outreach). } \\
\text { Advancement office and external } \\
\text { partners are separate from the } \\
\text { academic culture. }\end{array}$ & $\begin{array}{l}\text { Belief that knowledge lies inside } \\
\text { and outside of traditional } \\
\text { boundaries. } \\
\text { - Advancement office and external } \\
\text { partners are part of higher } \\
\text { education's teaching and learning } \\
\text { community. }\end{array}$ \\
\hline $\begin{array}{l}\text { Philosophy of advancement } \\
\text { (adapted from Hutchinson } \\
\text { and Huberman, 1993) }\end{array}$ & $\begin{array}{l}\text { Dissemination paradigm } \\
\text { Spread: One-way broadcast of } \\
\text { institutional work and programs } \\
\text { to “sell" to external stakeholders } \\
\text { Choice: External relations officers } \\
\text { seek to match institution's work } \\
\text { with stakeholder interests. }\end{array}$ & $\begin{array}{l}\text { Systemic change paradigm } \\
\text { Exchange: Stems from a public } \\
\text { agenda, institutions and external } \\
\text { partners exchange perspectives, } \\
\text { knowledge, materials, and resources } \\
\text { for public benefit. } \\
\text { Implementation: Interactive process } \\
\text { of solving societal problems and } \\
\text { bringing about systemic change. }\end{array}$ \\
\hline $\begin{array}{l}\text { Structured participation } \\
\text { strategies }\end{array}$ & $\begin{array}{l}\text { Alumni, donors: Home and office visits, } \\
\text { college advisory board memberships, } \\
\text { campus visits. Development staff } \\
\text { "prioritize, show, tell, solicit" } \\
\text { State relations: Legislative campus } \\
\text { visits, capitol visits. Government } \\
\text { relations staff "prioritize, show, } \\
\text { tell, solicit" } \\
\text { Corporate and foundation relations: } \\
\text { Office visits, campus meetings, and } \\
\text { tours, match interests of foundations } \\
\text { and corporations. } \\
\text { Community relations: promote campus } \\
\text { outreach with community partners. }\end{array}$ & $\begin{array}{l}\text { Discovery teams: Interdisciplinary } \\
\text { cross-stakeholder teams consisting of } \\
\text { institutional partners (faculty, staff, } \\
\text { students) and external stakeholders } \\
\text { (alumni, donors, foundation officers, } \\
\text { legislators, community partners, } \\
\text { corporate partners) to promote } \\
\text { education, dialogue, advocacy, and } \\
\text { financial support for public agenda. } \\
\text { Interdisciplinary councils: Federation } \\
\text { of discovery teams to promote } \\
\text { education, dialogue, advocacy, and } \\
\text { financial support for public agenda } \\
\text { (e.g., Council on Environmental } \\
\text { Stewardship, Council on Cultural } \\
\text { Enrichment) }\end{array}$ \\
\hline
\end{tabular}


Table 2: Continued

Traditional model of advancement

- Promote opportunities to be supported by stakeholders (lobbying, donor solicitation).

Role of advancement staff (boundary spanning roles) students

Role of deans, chairs, and central administration

Development cycle (major gift fundraising)
- Promote interests of dean, institution, select faculty

Role of faculty, academic staff,
Faculty and staff: Passive unless program is a college priority. Featured speaker in "show and tell" to legislative staff, alumni, donors. May have separate corporate or community relationships. Students: Passive beneficiaries of support. Serve as marketing tools. May participate in service learning or corporate internship.

- Seek support for individual school, college, departmental, and institutional needs. Convene and direct activities of advisory boards, corporate roundtables, legislative visits around these needs.

- Retain primary solicitation and stewardship responsibilities based on institutional needs.

Prospect identification: By college, department affiliation, degree of alumnus.

Cultivation: Development officer visit, dean, faculty contact, College Board of Visitors membership, campus visits Solicitation: Development officer, dean match donor interests with department or college needs

Stewardship: Recognition and ongoing contact with project/program.
Engagement model of advancement

- Facilitate stakeholder participation in discovery teams, councils, student learning programs

- Solicit financial, political, volunteer support for public agenda.

Faculty and staff: Active participant or facilitator of discovery teams and student learning programs in collaboration with external partners Students: Active learning participant on discovery team and learning programs. Fully engaged with external partners.

- Articulate overall vision and needs of the school/college/ institution in the context of the public agenda. Solicit support to meet these needs.

- Facilitate creation of council and discovery team leadership and stakeholder selection.

- Assume solicitation responsibilities in the context of institutional and team/council needs

Prospect identification: "Open agenda" Identify prospects by area of interest. Direct prospect to appropriate discovery team and council within the public agenda. Cultivation: Participation on discovery team, Council member, development officer visits, dean, faculty contact.

Solicitation: Development officer, discovery team leader match gift to advance team and council progress. Stewardship: Recognition and continued work on discovery teams and councils. philosophy, acknowledging that faculty, students, public officials, community partners, and corporate partners all bring unique perspectives and new knowledge important to addressing societal issues. Unlike the traditional model where institutional and stakeholder knowledge and cultures remain separate, the engagement model produces shared culture, shared 
knowledge, and a shared vision around issues critical to our society.

Third, student and faculty learning and research are greatly enhanced in the engagement model. Interdisciplinary collaboration thrives in the discovery team model since broad issues, not narrow disciplines, set the agenda for problems to be addressed. An exciting prospect is that students could use discovery teams to conduct research, make professional contacts, and share insights about their academic experiences. Unlike passive observers in the traditional advancement model, faculty and students in the engagement model have a permanent seat at the table to dialogue with stakeholders about future directions for their field.

Finally, the discovery teams may be the perfect vehicle to engage the next generation of major donors. As this paper previously outlined, these new donors are likely to make transformational gifts to programs that align with their values and have a clear impact on society. Donor prospects' participation on issueoriented teams may stimulate opportunities for transformational gifts. This is possible because the engagement model focuses on ideas and systemic change, compared to the traditional advisory board model focusing on programmatic needs of colleges and departments. In short, councils and discovery teams may provide a compelling new structure for cultivating the next generation of major donors.

Table 2 illustrates the traditional and engagement models of institutional advancement through the lens of the knowledge flow framework.

\section{Conclusions}

Public colleges and universities today face enormous fiscal, political, and structural challenges. Demographic changes, globalization, and declining financial and political support for higher education have led institutional advancement leaders to consider numerous strategies for supporting their campuses. As articulated in this paper, however, these strategies have significant limitations and lead to further erosion of the "public" in public higher education.

Relying on current advancement strategies inevitably leads to negative consequences for higher education and society. Quality, access, and affordability of higher education are threatened under current conditions where public support is declining and market forces strengthening. Consequently, the divide between public higher education and society will continue to widen, and the ivory tower legacy of colleges and universities prevails. Maintaining the status quo means that institutions and external stakeholders will continue to operate in separate cultures, unable and unwilling to create a unified vision for improving quality of life in this country and around the world.

I conclude suggesting that the engagement model outlined in this paper provides a compelling alternative for restoring the public ideals of public higher education, while leveraging public and private support for its programs. Institutions that make the transition from a linear, unidirectional model of knowledge transfer to a constructivist paradigm of systemic change have the potential to yield significant benefits to their campus and society at large. 
Institutions benefit by enriching their teaching, learning, and interdisciplinary research programs while strengthening public and private support for these programs. Engagement helps faculty and academic staff by improving the quality and support for teaching, research, and service programs.

Graduate and undergraduate students have much to gain since engagement facilitates interdisciplinary training, informs future research agendas, establishes career connections, and enriches overall learning. The engagement model holds great promise for preparing the next generation of donors, public servants, scholars, business leaders, and community leaders.

The engagement model yields great benefits to external stakeholders. In this new paradigm, alumni, donors, and prospects become true partners in teaching, learning, and discovery. The result of this empowerment is engaged and enthusiastic individuals who may be more inclined to make a major gift. Similarly, public officials and community partners benefit by having a forum to dialogue and gain new perspectives on issues of public concern. The result is more-informed policy development and potentially a rekindling of confidence and support for higher education. Finally, corporate partners in this model may develop a more acute awareness of their market role and expand opportunities for commercialization, business development, and student recruiting. In short, engagement model of institutional advancement establishes a template for creating a "public purpose university" (see Lyall and Sell, 2006) that addresses societal issues and generates long-term trust and support for higher education.
A Long Road Ahead... Adopting the engagement model requires a fundamental shift in how colleges and universities think about and perform their role in knowledge creation, dissemination, and implementation. Consequently, enormous cultural and structural changes must take place in both academic and advancement circles to move in the direction of engagement.

Faculty culture is a key barrier to implementing the engagement model. University faculty are socialized within traditional views of higher education and place boundaries on what constitutes "appropriate academic behavior." These traditional views advance restrictive definitions of research and promotion that inhibit work with outside stakeholders (Dickson et al., 1985). Most importantly, poor faculty-reward systems are barriers to faculty members' involvement with service programs (Seldin, 1982).

For the engagement model to take hold on campuses, leaders must provide faculty incentives such as discovery team seed grants or graduate assistants to support their participation. Since faculty rewards are primarily tied to research productivity, discovery teams and councils must clearly support engaged scholarship that corresponds with promotion and tenure guidelines. Similarly, new structures must be developed to support engagement since breaking down academic barriers requires significant attention to organizational structures, management, and budgeting (Amey et al., 2002).

Beyond faculty rewards, the engagement leaders must address enormous power issues between 
institutions and stakeholders. In the engagement model, higher education leaders face the challenge of sharing power with a diverse group of stakeholders. The engagement model leaves the door open for reforms and new ideas regarding teaching, research, and service. Uneven distribution and application of power can however, lead to disagreements over the meaning of issues and events among stakeholders. For this reason, institutional decisions and reforms must flow from a shared culture. Consensus between partners must be achieved through negotiation and strife (Dantnow, 1998).

Institutional advancement culture, rewards, and structures would also have to change dramatically to accommodate the engagement model. Major gift programs provide a compelling example. Today, development officers are under tremendous pressure to cultivate their alumni to support their programs in their college. This territorial nature of major gift fund raising often conflicts between colleges, departments, advancement officers, and sometimes donors themselves.

The problem is that development officers are typically rewarded for bringing donors to support individual college or departmental programs. A new system must emerge where development officers are rewarded for identifying, cultivating, soliciting, and stewarding major gift prospects who possess knowledge, compelling interests, and financial or political capital to advance a shared public agenda. Government relations, corporate and foundation relations, and community relations officers may benefit from a similar model.
Finally, I acknowledge that my analysis has been limited to an institutional perspective. Future analyses must consider how or the extent to which external partners may be integrated into the engagement model. For example, can we assume that public officials have the time and interest to be deeply engaged in the work of the university as espoused in this model? Also, does enough trust exist between campus leaders and external partners for this model to work effectively? If not, how do we build that trust? In addition, what are the appropriate boundaries between stakeholder input into a public agenda and institutional control of the leadership and management functions of the university? Related to these issues, we must realistically consider the extent to which an engaged university can solve the many ills facing society today. Because societal problems are deeply rooted and take generations to address, the university should be viewed as an important partner in tackling these issues but cannot be held accountable for solving them quickly. At the same time, genuine support and participation among external partners may give institutions the best chance of making a difference.

Former President of the National Association for State Universities and Land Grant Colleges, C. Peter Magrath, summed it up best, "Public universities must be financially stable and enjoy public confidence in order to perform their vital mission as the intellectual and educational service centers for America in the 21st Century. But to earn this support, they must examine themselves... and then change and reform to better serve 
society." There is no doubt that shifting to an engagement model of advancement is a Herculean task. This effort is, however, critical not only to securing higher education's financial future but also to improving quality of life for the many communities served by higher education-both local and global.

\section{Acknowledgements}

The author wishes to thank Edward Reisner, Chris Richards, Kathleen Sell, and Kristi Thorson for their thoughtful comments on earlier drafts of this article.

\section{References}

American Association of State Colleges and Universities (2002), Stepping Forward as Stewards of Place, AASCU, Washington, DC.

Amey, M.J., Brown, D.F. and Sandmann, L.R. (2002), "A multi-disciplinary collaborative approach to a university-community partnership: Lessons learned," Journal of Higher Education Outreach and Engagement, 7, 3, pp. 19-26.

Baade, R.A. and Sundberg, J.O. (1996), "What determines alumni generosity?", Economics of Education Review, 15, 1, pp. 75-81.

Berman, P. and McLaughlin, M. (1978), Federal Programs Supporting Educational Change, Vol. 3, Rand Corporation, Santa Monica, CA.

Big Ten Government Relations Conference (September 28, 2004), Costs of Government/ Costs of Higher Education-Emerging Issues, University of Wisconsin-Madison, Madison, WI.

Boverini, L. (2006), "When venture philanthropy rocks the ivory tower," International Journal of Educational Advancement, 6, 2, pp. 84-106.

Boyer, E.L. (1990), Scholarship Reconsidered, Carnegie Foundation for the Advancement of Teaching, Princeton, NJ.

Boyer, E.L. (1996), "The scholarship of engagement," Journal of Higher Education Outreach and Engagement, 1, 1, pp. 11-20.

Brainard, J. (2002), "U.S. agencies look to interdisciplinary science," Chronicle of Higher Education, 48, p. A20.

Bringle, R.G. and Hatcher, J.A. (2000), "Institutionalization of service learning in higher education," Journal of Higher Education, 71, 3, pp. 273-290.
Carnegie Foundation for the Advancement of Teaching (2006), Classification Descriptions, Available online: http://carnegiefoundation. org/classifications.

Clotfelter, C.T. (2003), "Alumni giving to elite private colleges and universities," Economics of Education Review, 22, 2, pp. 109-120.

Couturier, L.K. (2003), "Balancing state control with society's needs," Chronicle of Higher Education, 49, 42, p. B20.

Dantnow, A. (1998), The Gender Politics of Educational Change, Falmer, London.

Dickson, A., Gallacher, J., Longden, B. and Bartlett, P. (1985), "Higher education and the community," Higher Education Review, 17, 3, pp. 49-58.

Duderstadt, J.J. (2003), A University for the 21st Century, University of Michigan Press, Ann Arbor, MI.

Ehrenberg, R.G. (2006), What's Happening to Public Higher Education?, Greenwood Press, Portsmouth, NH.

Glassick, D.C., Huber, M.T. and Maeroff, G.I. (1997), Scholarship Assessed: Evaluation of the Professorate, Jossey-Bass, San Francisco, CA.

Grace, K.S. and Wendroff, A.L. (2001), High Impact Philanthropy: How Donors, Boards, and Nonprofit Organizations Can Transform Communities, John Wiley and Sons, Inc., New York.

Gray, D. (2005), “Development for deans Annual training program sponsored by the Council for the Advancement and Support of Education (CASE), Washington, DC.

Higher Education Learning Commission (2006), Institutional Accreditation: An Overview. Available online: http://www.ncahlc.org/ download/2003OVERVIEW.pdf.

Holland, B.A. (1997), “Analyzing institutional commitment to service: A model of key organizational factors," Michigan Journal of Community Service Learning, 4, pp. 30-41.

Hood, P. (2002), Perspectives on Knowledge Utilization in Education, WestEd, San Francisco.

Hutchinson, J. and Huberman, M. (1993), "Knowledge dissemination and use in science and mathematics education: A literature review", Prepared for the Directorate of Education and Human Resources, Division of Research, Evaluation and Dissemination, National Science Foundation, Washington, DC.

Jacobson, J. (2004), "In baby boomlet, number of new high school graduates is projected to rise," Chronicle of Higher Education, 50, 22, p. A28.

Kellogg Commission on the Future of State and Land-Grant Universities (1999), Returning to our Roots: The Engaged Institution, National 
Association of State Universities and Land Grant Colleges, Washington, DC. Available online: http://www.nasulgc.org/publications/Kellogg/ Kellogg1999_Engage.pdf.

Knox, A.B. (2001), "Assessing university faculty outreach performance," College Teaching, 49, 2, pp. 71-74.

Learn and Serve America (2006), What is ServiceLearning? Available online: http://www. learnandserve.gov/about/service_learning/index. asp.

Lyall, K.C. and Sell, K.R. (2006), "The de facto privatization of American public higher education," Change, 38, 1, pp. 6-13.

Lynton, E.A. (1995), Making the Case for Professional Service, American Association for Higher Education, Washington, DC.

March, J.G. (1981), “Decision-making perspective: Decisions in organizations and theories of choice," in Van de Ven, A.H. and Joyce W.F. (eds.), Perspectives on Organization Design and Behavior, John Wiley and Sons, New York. pp. 427-468.

Maurrasse, D.J. (2001), Beyond the Campus: How Colleges and Universities Form Partnerships with their Communities, Routledge, New York.

Monks, J. (2003), "Patterns of giving to one's alma mater among young graduates from selective institutions," Economics of Education Review, 22, 2, pp. 121-130.

Mortenson, T. (2004, January), "Postsecondary Education OPPORTUNITY 139, Mortenson Research Seminar on Public Policy Analysis of Opportunity for Postsecondary Education, Oskaloosa, IA.

Mundy, P. (1992), "Information sources of agricultural extension specialists $\mathrm{PhD}$ dissertation, University of Wisconsin-Madison.

National Center for the Dissemination of Disability Research (1996), A Review of the Literature on Dissemination and Knowledge Utilization, Southwest Educational Development Laboratory, Austin, TX.

National Forum on Higher Education for the Public Good (2006), Now More Than Ever: Higher Education for the Public Good. Available online: http://www.thenationalforum.org/archives/news/ nowmorethan.htm.

National Service-Learning Clearinghouse (2006), Welcome to Service-Learning. Available online: http://www.servicelearning.org/welcome_to_ service-learning/index.php.

Newman, F., Couturier, L. and Scurry, J. (2004), "Higher education isn't meeting the public's needs," Chronicle of Higher Education, 51, 8, p. B6.

Peters, S.J., Jordan, N.R., Adamek, M. and Alter, T.R. (2005), Engaging Campus and Community:
The Practice of Public Scholarship in the State and Land Grant University System, Kettering Foundation Press, Dayton, OH.

Pfirman, S.L., Collins, J.P., Lowes, S. and Michaels, A.F. (2005), "Collaborative efforts: Promoting interdisciplinary scholars," Chronicle of Higher Education, 51, 23, p. B15.

Porter, J.R. (2006), "Minority-student enrollment climbs," Chronicle of Higher Education, 53, 12, p. A39.

Potter, W. (2003), "Public colleges try to show their value to states, but not everyone is convinced," Chronicle of Higher Education, 49, 35, p. A26.

Powers, J.B. (2006), "Between lab bench and marketplace: The pitfalls of technology transfer," Chronicle of Higher Education, 55, 5, p. B18.

Pulley, J.L. (2003), "Struggling against the tide: Ambitious fundraising campaigns press on despite the economic downturn and world events," Chronicle of Higher Education, 45, 25, p. A29.

Sandmann, L.R. and Weerts, D.J. (2006), Engagement in higher education: Building a federation for action. Report of the proceedings for a Wingspread Conference establishing the Higher Education Network for Community Engagement (HENCE), Racine, WI. Available online: http://www.henceonline.org/.

Seldin, C.A. (1982), "Off campus in-service activities: A status report,” Educational Research Quarterly, 7, 2, pp. 31-41.

Slaughter, S. and Leslie, L. (1997), Academic Capitalism: Politics, Policies and the Entrepreneurial University, Johns Hopkins University Press, Baltimore, MD.

St. John, E.P. and Parsons, M.D. (2004), Public Financing of Higher Education: New Contexts and Changing Rationales, Johns Hopkins Press, Baltimore, MD.

Thelin, J. (2004), A History of American Higher Education, Johns Hopkins Press, Baltimore, MD.

Votruba, J.C. (1996), "Strengthening the university's alignment with society: Challenges and strategies," Journal of Public Service and Outreach, 1, 1, pp. 29-36.

Walshok, M.L. (1999), "Strategies for building the infrastructure that supports the engaged campus," in Bingle, R. G., Games, R. and Malloy, E.A. (eds.), Colleges and Universities as Citizens, Allyn and Bacon, Boston, MA.

Ward, D. (2000), "Catching the waves of change in higher education," Educause. Available online: http://www.educause.edu/ir/library/pdf/ ERM0012.pdf.

Ward, K. (1996), "Service learning and student volunteerism: Reflections on institutional commitment," Michigan Journal of Community Service Learning, 3, pp. 55-65. 
Weerts, D.J. (2002), State Governments and Research Universities: A Framework for a Renewed Partnership, RoutledgeFalmer, New York.

Weerts, D.J. and Ronca, J.M. (2006), “Examining differences in state support for higher education: A comparative study of state appropriations for research universities," Journal of Higher Education, 77, 6, pp. 935-965.
Woo, S. (2006), "Report predicts rapid growth in minority-student enrollments," Chronicle of Higher Education, 53, 6, p. A44.

Yudof, M.G. (2002), "Is the public research university dead? Chronicle of Higher Education, V. 48 , p. B24.

Zlotkowski, E. (1998), Successful Service-learning Programs: New Models of Excellence in Higher Education, Anker Publishing Company, Inc., Bolton, MA. 